\title{
XXVI. A short account of the mammoth
}

\section{Mr. Rembrandt Peale}

To cite this article: Mr. Rembrandt Peale (1802) XXVI. A short account of the mammoth , Philosophical Magazine Series 1, 14:54, 162-169, DOI: 10.1080/14786440208676178

To link to this article: http://dx.doi.org/10.1080/14786440208676178

$$
\text { 曲 Published online: } 18 \text { May } 2009 .
$$

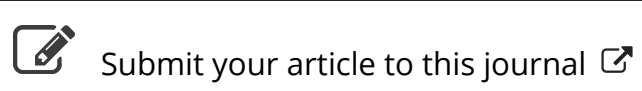

\footnotetext{
Џll Article views: 7
}

Q View related articles $\asymp$ 
comparifon, many of whofe difcriminations of ftrength being, as I had reafon to believe, nerely conjectural.

Before I proceed to explain Mr. Gilpin's tables, and the columns adder to them, it becomes neceffary to define what is meant by the term pure jpirit, and to inquire whether the fpirit which fir Charles defcribes can with propriety be called fuch.

"The firft ftep (fays he, in the Report made on this fubject in $179^{\circ}$ ) towards a right performance of the experiments, was to procure the two fubllances with which they were to be made, as pure as poffible. Diftilled water is in all cafes fo nearly alike, that no diffeulty occurred with regard to it ; but the fpecific gravity of pure fpirit, or alcohol, has been given fo very differently by the authors who have treated of it, that a particular fet of experiments appeared neceffary for determining to what degree of ftrength reetified fpirit could conveniently be brought. The perfon engaged to make thefe experiments was Dr. Dollfufs, an ingenious Swirs gentleman, then in London, who had diftinguithed himfelf by feveral publications on chemical fubjects. Dr. Dollfuls, having been furnithed by government with fpirit for the purpofe, reetified it, by repeated and flow diftillations, till its fpecifie gravity became ftationary in this manner of operaling: he then added dry caufic alkali to it, let it ftand for a few days, poured off the licguor, and difitled it with a fmall addition of burnt alum, placing the receiver in ice. By this method he obtained a firit whofe fpecific gravity was 8 I 88 , at 60 of heat. Perceiving, however, that be could not conveniently get the quantity of fpirit he wanted lighter than $8252 \%$, at 60 , be fixed upon that ftrength as a ftandard.

Several highly refpectabie authorities might be produced to prove this fpecific gravity to be a proper ftandard for pure spirit.

[To be continucd.]

XXVI. A flort Account of the Manmoth. By Mr. ReMBHANDT PEALE*.

THE mammoth is fo called from the Ruffian name, fuppofed to have been derived from the Hebrew Bebemotb, Job, chap. xl. It is properly continued, both words being expreffive of a large and extraordinary animal.

For a number of years pat many large and extraordinary

* Cumrunicated by the Autlor.

bones 
bones and teeth have been difcovered both in Siberia and America, which at firft were generally attributed to the elephant *, except fome very large teeth of the carnivorous kind totally different from thofe of any animal known.

In Siberia they were attributed to the mammoth, whofe fabulous exiftence they fuppofed to be under ground, and of which Ibrand ldes pretends to give a defcription. In North America thefe large bones and carnivorous grinders bave bcen found in great abundance on the Ohio and its tributary ftreams, walhed from their banks, or difcovered by digging in falt moraffes in the ncighbourhood of Cincinati; where they are found intermixed with the bones of buffaloes and deer, which a tradition of the Indians ftates to have been deftroved by a herd of thefe animals which came upon them from the north. This event happened, the Indians believe, as a punithment for their fins; but they fay the good fpirit at length interpofed to fave them, and, feating himfelf on a neighbouring rock, where they thow you the print of his feat and of one foot, burled his thunderbolts among them. All were killed except one male, who, prefenting his forehead to the thafts, thook them off, until, at length wounded, be fprung over the Wabanh, the Illenois, and the Great Lake, where he ftill lives.

Thefe bones were forwarded with great eagernefs to all parts of Europe, and depofited in mufeums, where they attracted the curiofity of all naturalifts, whofe conjectures and theories on them were very various, until Dr. Hunter, by a more accurate comparifon between them and the bones of other animals, determined that they mutt have belonged to a large non-defcript animal of the carnivorous kind, fomewhat refembling the hippopotamus and the elephant, yet effentially different from both.

The fubjest is now completely elucidated. Not long fince fome farmers in the State of New York, in America, digging marle from their morafes in the neighbourhod of NewWindfor, accidentally difcovered feveral of thefe bones, which were preferved by phyficians in the neigh bourhood. In the autumn of $180 \mathrm{r}$, my father Charles W. Peale and myfelf, having obtained poffeffion of thefe bones, perfevered for nearly three months, at the expenfe of much time, labour, and money, in a fearch for the remainder of the animal; and were fortu-

. Naturalifts were led to this idea in confequence of finding, in a few
infances in America, but frequently in Siberla, fome large gramibivorous
teeth, which probably belonged to an animal of the elephan kind, thrugh
certainly of diferent fpecies from any known : thefe teeth are remarkable for
bze, and in the number of lumellated vems of enamel which pervade them. L 2 nate 
nate enough to obtain two Reletons, found in two diftinct fituations, and unmixed with bones of any other individual whatever: one of thefe is preferved in the Mufeum at Philadelphia, and the other is now exhibiting in the Old Academyroom, Pall-Mall, previouny to its being taken to Paris.

The fkeleton of the manmoth bears fome general refemblance to that of the elephant, yet on examination even the general figure is found to be confiderably different; principally in the effect of the tuks, ftructure of the head, prominence and pointednels of the back over the fhoulders, its great defcent thence to the hips, together with the comparative fmallnefs of the body and the neceffarily detached effect of the hind-legs-proofs of greater activity than in the elephant. On a clofer examination, the characteriftic features are greally multiplied; and with refpect to the hind-legs, the idea of activity is confirmed from the fructure of the thighbones, which are extremely broad and flat, and well adapted for great exertions of ftrength, beyond that of the elephant, whole thigh-bones are not flat, but round. This effect of ftrength likewife prevails in the ribs, which are of a very unufual fructure, being bent edgcwife and having their greateft thicknefs at top, gradually becoming fmaller towards their junction with the cartilage; whereas in the elephant they are bent flatwife, like thofe of the ox, and are narrow at top and broad at the lower ends. This peculiarity in the ribs of the mammoth is worthy of particular notice, not only on account of the unufual pofition of ftrength, but becaufe, from their diftance between each other, they how the animal to have had confiderable flexibility in its body; to which the breadth and proximity in the ribs of the elephant, as well as the ox, are a certain impediment. Bcfides, as I obferved before, the budy is comparatively finallic, in confequence of the fmall length of the ribs.

The fpines of the back over the fhoulders are of an unufual magnitude, which gives the appearance of a hump, like the bifon, and are calculated to give power and motion to the head. Thofe in the elephant are not fo large over the thoulders, but much more fo all the way to the facrum : confequently his back is more arched. The proportionate length of the proceffes from the fpine of the fcapula differs effentially from all other animils. And, independently of any other variation in form, all the bones, of the limbs in particular, are aftonifhingly thick and ftrong.

We now come to the head, where the mof friking features of this animal are to be found; and fince between the correfponding parts of all animals there is a geveral analogy, it is 
the province of comparative anatomy not only to trace out the points of diftinction, but, fince they originate from certain fixed principles, in the difcrimination of variations, to confirm their propriety by an examination of the principles on which they are founded.

Although it is fufficiently evident to thofe who are accuftomed to this kind of inveltigation, from the obfervation of a few facts, that this animal nult have been carnivorots ; yet to others it is necellary to introduce every proof and conclufive evidence. Many perfons, from a falfe impreffion, believe that teeth are determined to be carnivorous merely from their having a rugged furface: with this opinion they very properly ank, "May not the vegetable food be of a coarfer quality?" It is true that the furface is rougheft on thofe graminivorous teeth which are employed in the maftication of the coarfeft regetable fubftances, not only becaufe luch roughnefs is requifite, but becaufe the teeth are rendered fo from the quality of the food, the bony interfices wearing down more eafily than the ridges of enamel, which operate as the roughnefs in a mill-ftone. It is not therefore from this fpecies of roughnefs that we prefume on fo important $a$ determination: the roughnefs exifting on the furface of calnivorous teeth is of another nature, much more ftrongly marked, and far from being rendered to by ufage : the more they are uled, the more even do they become. The toith of a graminivorous animal is compofid of alternate veins of enamel and bone, which thus pertade the whole mafs: thofe of carnivorous animals are covered with a hell or cruft of enamel, which is merely external, and exifts as well in the cavities as on the ridges; which is not the cafe witl other teeth. This enamel is required in the cavities, becaufe the teeth interlock with each other, the prominences ftriking into the cavities.

An uniform compofition of tooth, as it refpects the intermixture of enanel and bone, is obferved to prevail in thofe of the elephant, horfe, ox, \&c. principally differing from each other in the figute which thofe veins of enamel alfume, and by which alone they may be difcriminated among themfelves. On the otber hand, carnivorons teeth, incrufted with enamel as far as the gums, yet vary in the form and number of their protuberances, fo as generally to defignate their fpecies : yet among them there is a very proper diftinction to be oblerved, which is, that thofe carnivorous animals, the form of whole teeth and the attachment of whofe jaws allow them the fide or grinding motion, are always of the mixt kind. Nan, the monkey, hog, \&c. are carnivorous aniL 3 mals, 
mals, becaufe their teeth are incrufted with enamel, and becaufe they do eat fleth ; yet they are adapted for other food, by the rotatory motion of their jaws and the form of their teeth: this rotatory motion does not exift in the jaws of thofe animals which live entirely upon ften; for they are attached by an oblong head or procels inferted into a tranfverfe groove, and confequently have no other motion than up and down. In graminivornus animals the under jaw is attached by means of a confuderably round head (condyloid procefs) to a prominence or flat furface, fo that they rotate; and, to favour this motion, the coronoid procefs is generally thicker and not fo long as the condyloid; whereas in carnivorous animals the coronnid procefs is extremely flat and long, being never acted on except lengthwife.

But it muft not even be fuppofed that an animal may be of the mixt kind, unlefs we obferve a capacity for maftication; without which we muft declare it exclufively carnivorous.

Some object to the carnivorous nature of the mammoth from its not having cutting or canine teeth. To this it may be replied, that if we form our rule of judgment, as to what conftitutes a graninivorous animal, from the conftruction of an ox's jaw, the elephant would certainly be excluded, becaufe it has not incifires at leaft in the lower jaw : the fact is, that all carnirorous as well as graminivorous animals differ among themfelves with refpect to the number and fituation of their teeth; and hence they afforded to the fagacious and celebrated Limneus the moft infallible method of clafification, which has fuce been adopted, either wholly or partially, by all naturalifts. The probofcis of the elephant anfwers the purpose of incifores : he thercfore requires no others than grinders, which entircly fill his jaw's : hence he is completely graminivorous. And ahhough the mammoth is deficient in cutting teeth, and has no other canine teeth than his enormous thiks, the deficiencies of which nay have been fupplied by a pair of large and powerful lips, indicated by the uncommon fnuofity on the front of the lower jaw; yet I am decidedly of opinion, fince it cannot be contradicted by a fingle proof or fact, that the nammoth was exclufively carnivorous; by which I mean, that he made no ufe of vegetable food, but either lived cntirely on fefh or fint; and not improbably upon hell fifh, if, as there are many reafons to fuppofe, he was of an amphibious nature. I therefore only require affont to thefe facts: ift, The teeth are certainly of the carnivorous kind: 2 dly, They are not of the mist kind, becaule they have not the leaft rotatory motion, 
and fo completely lock together: $3 \mathrm{dly}$, Since, therefore, they are not graminivorous, fince they camnot be of the mixt kind, from a defect in motion, tiney mult be exclufively and pofitively carnivorous.

Independently of the teeth, the under jaw of the mammoth differs moft effentially from that of the elephant, which in its outline is femi-circular, from the condyle to the chin; whereas in the mammoth the outline is diftinetly anguiar, and is much greater in the length that it is in the bejght, which is the reverfe in the elephant: beticles fereral other ftriking diftinctions in botb jaw's.

When the 1keleton was firlt ereeted, I was much at a lofs how to difpofe of the turks; their fockets thowed that they grew out forwards, but did not indicate whether they were curved up or down. I chofe, therefore, firft to turn them upwards, not becaufe they produced the fame effect as in the elephant, for it is evident they could not in any pofition, owing to two circumftances. In the elephant, taking the level of the teeth for a horizontal bale line, the condyle of the neck is at right angles with it; and the perpendicular, one third longer than the bafe line: hence they are ufefiul on every occafion, the tufks themfelves being nearly ftraight, and pointing downwards; whereas in the manmoth, taking the level of the teeth for a bale line, the condyle of the neck is fituated but a few inches above it: confequently the fockets for the turks and the condyle of the neck are in a horizontal direction: this circumftance, together with the extraordinary curve of the tukks, would raife the points in the air, directed in fome decree backivard over the head, twelve feet from the ground, and never could have beeu brought lower than fix or feven feet from it. This pofition was evideutly abfurd: I therefore refolved on reverfing them; in which pofition, in confequence of their witt or double curve, they appear infinitely more ferviceable.

Six miles from the fpot where this fkeleton was difcovered we found two entire tuks, in form exactly like thofe in the fkeleton, but very much worn at the extrenities (the point of one I have with me), and worn in fo peculiar a manner, confidering their form, as could not have happened in an elevated pofition; mlefs on the abfurd fuppofition, that the animal amufed himfelf with wearing and rendering them blunt, by rubbing them againft high and perpendicular rocks: this in a late of nature can never be fuppoled, whatever habits may be acquired when in a narrow confinement. There can be no doubt, then, of their having been ufed againt the ground, and not improbably in tearing up

$$
\mathrm{L}_{4} \text { hiel!: }
$$


thell-fifh, if, as we have many reafons to fuppofe, he was of an amphibious nature: for this fpecies of food his teeth feem admirably adapted. All animals of finilar babit-have fimi lar teeth : this animal has teeth unlike an wither with which we are acquainted: there is much ratuil, tles fore, in fuppofing his food to have been difierent; ef,ecinlly when we confider the thicknefs of enatrel which covers the teetio, he peculiar manner in which thes are worn, and the fiudl opening for the throat. But, whether anphibioss or unt in the inverted poition of the tulks lie could have tom an animal to pieces held benea $h$ his foot, and could hove itrick down an aninal of common fize, $x$ ithrut having his light obftructed, as it certainly would have been in the other pofition.

The tufks themfelves are compofed of two very cliftinet fubftances: the internal bony or ivorv part, which we find in the greateft ftate of decay; and a thick, diftinct coating, donbtlefs having undergone fome decay, yet at pretent abfolutely heavier and harder than the frefhelt ivory. No part of the fkeleton is petrified, but all in their prefent ftate of prefervation from having been furrounded by a calcareous foil, compofed principally of decared thells, and covered with water even in the drieft feafons.

How long fince thefe animals have exifter, we fhall perhaps ever remain in ignorance; as no judgment can be formed from the quantity of vegetable foil which bas accumulated over their bones. Ceriain we are, that they exifted in great abundance, from the number of their renains which are found in Anerica: we are likewife fure that they muft have been detiroyed hy fome fidden and powerful caufe; and nothing apnears nure probable than one of thofe deluges or fudden irruptions of the lea, which have left their traces in cvery part of the globe, and which are in amazing abundance on the very port where thefe bones are found: they confift of petrifactions of fea productions, fhells, corals, \&ce. It is extremely probable that, whenever and by whatever means the exirpation of this tremendous race of animals was effected, the fame caufe mult have operated in the deftruction of all thrfe mhabitants from whom we might have received fome fatisfactory account of them.

$$
\text { Dimenfins of the Skileton. }
$$

Height over the fhoulders

Dito over the hips

Length from the chin to the rump
Ft. In.

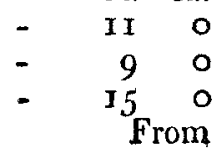


New Tbeory of the Confitution of mixed Gafes eluciduted. 169

From the point of the tulks to the end of the Ft. In. tail, following the curve - $\quad-3^{I} \circ$

Length in a ftraight line $\quad-\quad-\quad-\quad \begin{array}{lll}17 & 0\end{array}$

Width of the hips and body $\quad-\quad-\quad 58$

Length of the under jaw $\quad-\quad 5 \quad-\quad-\quad 210$

Weight of the fame - $\quad 63 \frac{3}{2}$ pounds

Width of the head - $\quad-\quad$ - 32

Length of the thigh-bone - - $\quad 37$

Smalleft circumference of the fame - $\quad-\quad$ I 6

Length of the tibia - $\quad-\quad 20$

Length of the humerus, or large bone of the fore-leg - $\quad-\quad$ - $\quad-2$ ro

Largeft circumference of the fame - - $32 \frac{\pi}{2}$

Smaileft ditto ditto $\quad-\quad$ - $\quad$ - $\quad$ I 5

Lengih of the radius - $\quad-\quad-\quad-25_{2}^{\frac{k}{2}}$

Circumference round the elbow $-\quad-38$

Length of the fcapula, or fhoulder-blade - 3 I

Length of the longeft vertebra, or back-bone $\quad 2 \quad 3$

Longeft rib, without cartilage - $\quad-47$

Length of the firft rib - $\quad-\quad-\quad-20$

Ditto of the breaft-bone - $\quad-\quad$ - 4 - 4

Length of the turks, defences, or horns - 107

Circumference of one tooth or grinder - $\quad$ I $6_{2}^{*}$

Weight of the fame, 4 pounds Io ounces

The whole fkeleton weighs about 1000 pounds.

XXVII. New Theory of the Conftitution of mixed Gafes elucidated. By J. Dalton, Efq.*

$I_{N}$ an effav, publifhed in the Memoirs of the Literary and Philofophical Society of Manchefter, vol. v. part 2, I gave a new theory of the conftitution of mixed gafes, and particularly of the atmofphere, and endeavoured to illuftrate my meaning by a plate, \&ce. Notwithftanding this, I am informed by fone of my chenical friends that they do not clearly underftand the hypothefis itfelf, and confequently are not able to judge of its merits or defects: and a late writer (Dr. Thomfon) in his Syftem of Chemiftry, vol. iii. p. 270, fpeaking of the uniform diffufion of the different gafes of the atmofphere, makes the following obfervation:- "Even Mr. Dalton's ingenious fuppofition, that they neither attract nor repel each other, would not account for this equal diftribution; for, undoubtedly on that fuppofition they would arrange

Communicated by the Author.

themfelves 